Int. J. Dev. Biol. 51: 731-738 (2007)

doi: $10.1387 / \mathrm{ijdb} .072442 \mathrm{ce}$

Short Communication

\title{
Interleukin-2 induces the proliferation of mouse primordial germ cells in vitro
}

\author{
CRISTINA EGUIZABAL \#,1, MARIA D. BOYANOํ, ALEJANDRO DÍEZ-TORRE², RICARDO ANDRADE², \\ NOELIA ANDOLLO ${ }^{1}$, MASSIMO DE FELICl ${ }^{3}$ and JUAN ARÉCHAGA*,1,2 \\ ${ }^{1}$ Laboratory of Developmental Biology and Cancer, Department of Cell Biology and Histology, Faculty of Medicine and Dentistry, \\ ${ }^{2}$ Facility for Biomedical Analytical and High Resolution Microscopy, University of the Basque Country, Vizcaya, Spain and \\ ${ }^{3}$ Section of Histology and Embryology, Department of Public Health and Cell Biology, University of Tor Vergata, Rome, Italy.
}

\begin{abstract}
Primordial germ cells (PGCs) are the stem cell precursors of the germ line. Several growth factors contribute to enlarging the PGC population by acting as mitogens, survival factors or both. Interleukin-2 (IL-2) has a growth-promoting activity for T and B-lymphocytes, but its role in PGCs had not yet been studied. Here, we show that PGCs isolated from 10.5, 11.5 and 12.5 day postcoitum (dpc) mouse embryos constitutively express the three subunits $(\alpha, \beta$ and $\gamma)$ of the IL2 receptor (IL-2R). In contrast, IL-2 mRNA was not detected in these cells. However, the addition of recombinant IL-2 to the culture medium increased the number of PGCs in vitro via a mitogenic effect, as indicated by bromodeoxyuridine incorporation assays. Neutralization of the IL-2 receptor using anti-IL-2R subunit antibodies inhibited this IL-2-mediated proliferative effect on PGCs from 11.5 dpc embryos. Together, these data are indicative of a paracrine effect of IL-2 on PGC proliferation. In this regard, we also compared the effect of IL-2 with other compounds such as basic fibroblast growth factor (bFGF), steel factor, leukemia inhibitory factor and forskolin, and found that the degree of proliferation induced by IL-2 was similar to that induced by bFGF and forskolin. These observations support the notion that similar patterns of molecular signaling may underlie the developmental pathways of hematopoietic and germ stem cell precursors.
\end{abstract}

KEY WORDS: germinal cell differentiation, hematopoietic stem cell, PGC, IL-2, embryonic hematopoiesis

Primordial germ cells (PGCs) are the stem cell progenitors of the germ line. They exhibit phenotypic differentiation without losing their pluripotency. In the mouse embryo, PGCs can be first detected around 7 days postcoitum (dpc) as a small cluster of alkaline phosphatase positive cells in the extraembryonic mesoderm, at the posterior region of the primitive streak and at the base of the allantois (McLaren, 2003). From this region, they move into the embryonic hindgut endoderm (8-9 dpc) and at $9.5 \mathrm{dpc}$ start to migrate actively from the hindgut wall towards the growing urogenital ridges, where they finally colonize the developing gonads at $12.5 \mathrm{dpc}$ (Molyneaux and Wylie, 2004). During their migratory phase, the PGC population expands from approximately 100 cells in $8.5 \mathrm{dpc}$ mouse embryos, to 3,000 cells in $11.5 \mathrm{dpc}$ embryos, reaching around 25,000 PGCs at $12.5 \mathrm{dpc}$ (Tam and Snow, 1981). By $12.5 \mathrm{dpc}$, PGCs in the male genital ridge start entering into mitotic arrest, whereas female germ cells arrest at meiotic prophase I, which takes place later at 13.5/15.5 dpc (McLaren, 2003).

Somatic cells contribute to the increase in PGC numbers by means of soluble growth factors, which are known to stimulate the proliferation and/or survival of mouse PGCs in culture (De Felici et al., 2004). For example, basic fibroblast growth factor (bFGF), tumor necrosis factor- $\alpha$ (TNF- $\alpha$ ) and bone morphogenetic protein4 (BMP-4) (Resnick et al., 1992) are mitogens for PGCs. In contrast, other cytokines such as interleukin-4 (IL-4), interleukin-6 (IL-6), interleukin-11 (IL-11) and leukemia inhibitory factor (LIF) have been found to enhance the survival rather than the proliferation of PGCs in culture (De Felici and Dolci., 1991; Cooke et al., 1996; Cheng et al., 1994; Koshimizu et al., 1996). Finally, Steel Factor (SF) is able to increase both PGC proliferation and survival

Abbreviations used in this paper: AGM, aorta-gonadomesonephros; AP, alkaline phosphotase; BMP, bone morphogenetic protein; BrdU, bromodeoxyuridine; dpc, days post coitum; F, forskolin; FGF, fibroblast growth factor; HSC, hematopoietic stem cell; IL, interleukin; LIF, leukemia inhibitory factor; PGC, primordial germ cell; SF, steel factor; TGF- $\beta 1$, transforming growth factor betal; TNF, tumor necrosis factor.

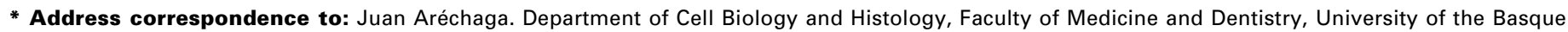
Country, E-48940 Leioa, Vizcaya, Spain. Fax: +34-94-601-3266. e-mail: juan.arechaga@ehu.es

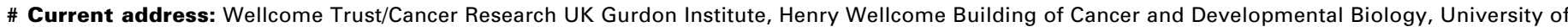
Cambridge, Tennis Court Road, Cambridge, CB2 10N, U.K.
} 
(Godin etal., 1991; Dolci etal., 1991, Pesce etal., 1993), whereas factors such as transforming growth factor- $\beta 1$ (TGF- $\beta 1$ ) and activin appear to negatively regulate PGC proliferation (Godin and Wylie, 1991).

Interleukin-2 (IL-2) is a potent, multifunctional cytokine that plays a central role in the growth-stimulatory activity of T lymphocytes. It also participates in multiple biological processes, including the growth and differentiation of $B$ lymphocytes, the liberation of lymphokine-activated killer lymphocytes and the proliferation and maturation of oligodendroglial cells (Gaffen and Liu, 2004). The biological effects of IL-2 are mediated by a specific cell surface receptor (IL-2R) which consists of three subunits (IL-2R $\alpha$, IL-2R $\beta$ and IL-2R $\gamma$ ), also known as p55, p75 and p64, respectively (Wang et al., 2005). The expression of different combinations of these three components gives rise to the generation of various subtypes of the IL-2 receptor, each of which exhibits different binding affinities for IL-2 (Kim et al., 2006). The IL-2R $\alpha$ subunit is responsible for specific binding of IL-2, whereas both the $\beta$ and $\gamma$ subunits increase the strength of ligand receptor binding and enable the receptor to transduce its signal to the cytoplasm (Wang et al., 2005). Recent studies have shown that the $\gamma$ chain is present as a functional subunit in many cytokine receptors, such as those for IL-4, IL-7, IL-9, IL-13, IL-15 and IL-21, (Noguchi et al., 1993; Giri et al., 1994; He and Malek, 1995; Sugamura et al., 1996; Asao etal., 2001). Consequently, it has been designated as the common $\gamma$ chain.

IL-2 is expressed in hematopoietic stem cells (HSC) in $7.5 \mathrm{dpc}$ embryos (Yoder, 2001, 2004). At this stage, HSCs are found in extraembryonic sites such as the yolk sac and the trophoblast, but at 10.5 to $12.5 \mathrm{dpc}$ they are also located in embryonic organs and regions such as the liver, thymus and the aortagonadomesonephros region (AGM) (Godin et al., 1995; Cairns et al., 2003), thus coinciding spatially with PGCs. The fact that the lineage specification of both cell types occurs within the same embryonic territory, at similar developmental stages and may be regulated by common genomic locihas led to the proposal that PGCs might be the precursors of HSCs or that they could have a common embryonic stem cell precursor. Indeed, EG-PGC-derived cells can be easily induced to differentiate into hematopoietic cells when cultured in methylcellulose in the presence of IL3 (Rich, 1995; Othaka, et al., 1999). Similarities between HSCs and PGCs led us to wonder if PGCs share also the mitogenic response to IL-2 previously observed in hematopoietic cells. In the present work, we show that the three subunits of IL-2R $(\alpha, \beta$ and $\gamma$ ), but not IL-2, are constitutively expressed on the surface of PGCs isolated from 10.5, 11.5 and $12.5 \mathrm{dpc}$ embryos and that this receptor mediates a mitogenic effect of IL-2 on PGCs cultured in vitro.

\section{Results and Discussion}

\section{Expression of components of the IL-2/IL-2R system}

The IL-2/IL2R system is normally expressed in T, B and NK lymphocytes to stimulate their proliferation via a community effect (Leonard et al., 1984). Other kinds of cells, such as dendritic cells (Granucci et al., 2001), macrophages (Gaffen and Liu, 2004) and

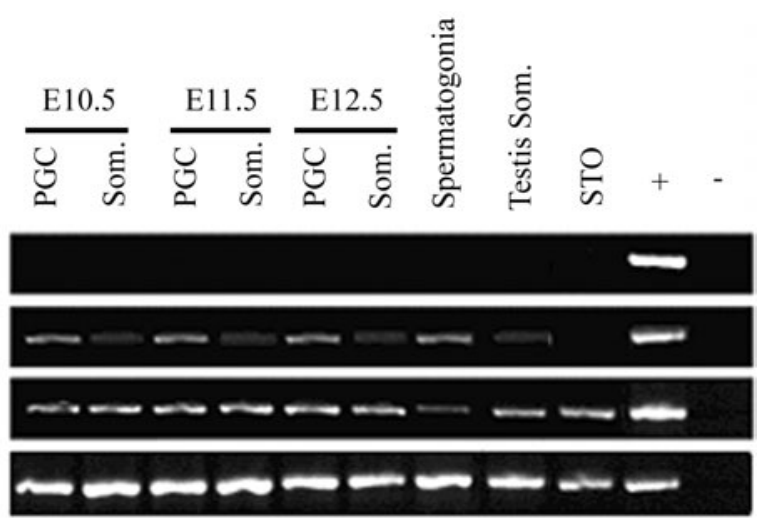

Fig. 1 (Left). Expression of IL-2, IL-2R $\alpha$ and IL-2R $\beta$ genes in primordial germ cells (PGCs) and somatic cells. The expression of IL-2, IL-2R $\alpha, I L-$ $2 R \beta$ and $\beta$-actin was analyzed by RT-PCR in PGCs and gonadal somatic cells from E10.5, E11.5 and E12.5 embryos, spermatogonia, isolated testis somatic cells and the STO mouse embryonic fibroblast cell line. RNA from murine splenic mononuclear cells activated with phytohemagglutinin-M was used as a positive control for IL-2, IL-2R $\alpha$ and IL-2RB.
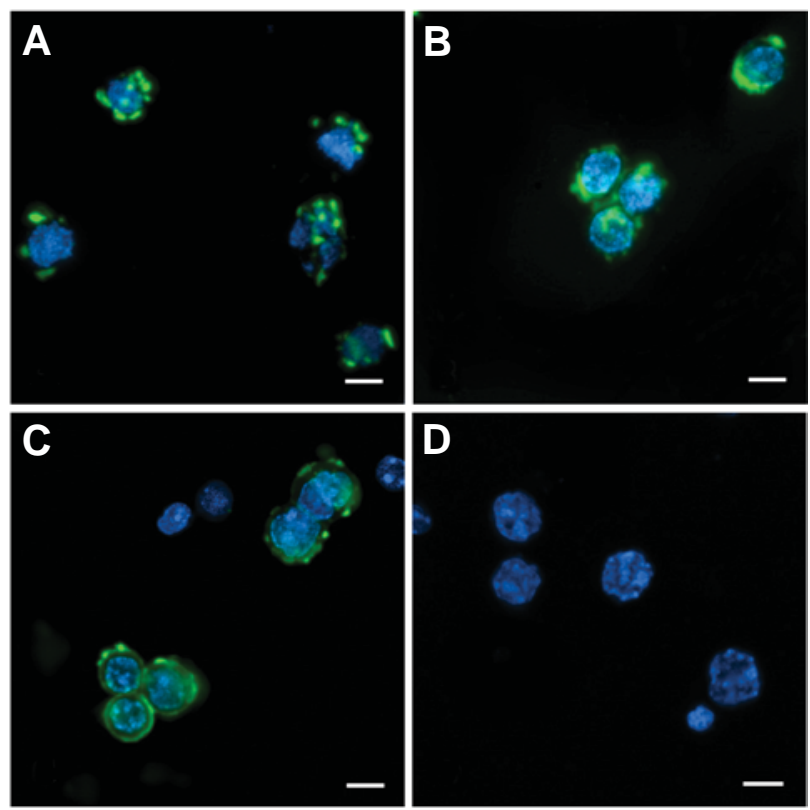

Negative controls (-) consisted of PCR reaction performed without cDNA. The sizes of the amplified products are shown in Table 1. The $\alpha$ and $\beta$ subunits of the IL-2R are expressed in PGCs and somatic cell samples at 10.5, 11.5 and $12.5 \mathrm{dpc}$, but IL-2 mRNA was not detected in any of them. Only the IL-2R $\beta$ subunit is present in the STO cell line.

Fig. 2 (Right). Immunolocalization of the $\boldsymbol{\alpha}, \boldsymbol{\beta}$ and $\boldsymbol{\gamma}$ subunits of IL-2R. Immunofluorescent confocal microscope images of PGCs from $11.5 d p c$

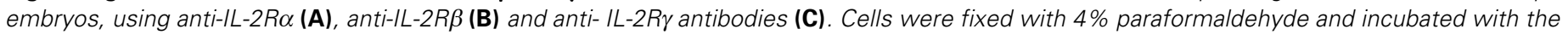
corresponding anti-mouse IL-2R $\alpha, \beta$ and $\gamma$ antibody, followed by FITC conjugated rat anti-mouse IgG. (D) As a negative control, PGCs were only incubated with the secondary antibody. All subunits were found to be located on the surface of PGCs. The objective used was $x 60$. The image format was $1024 \times 1024$ pixels. Bar, $10 \mu \mathrm{m}$. 

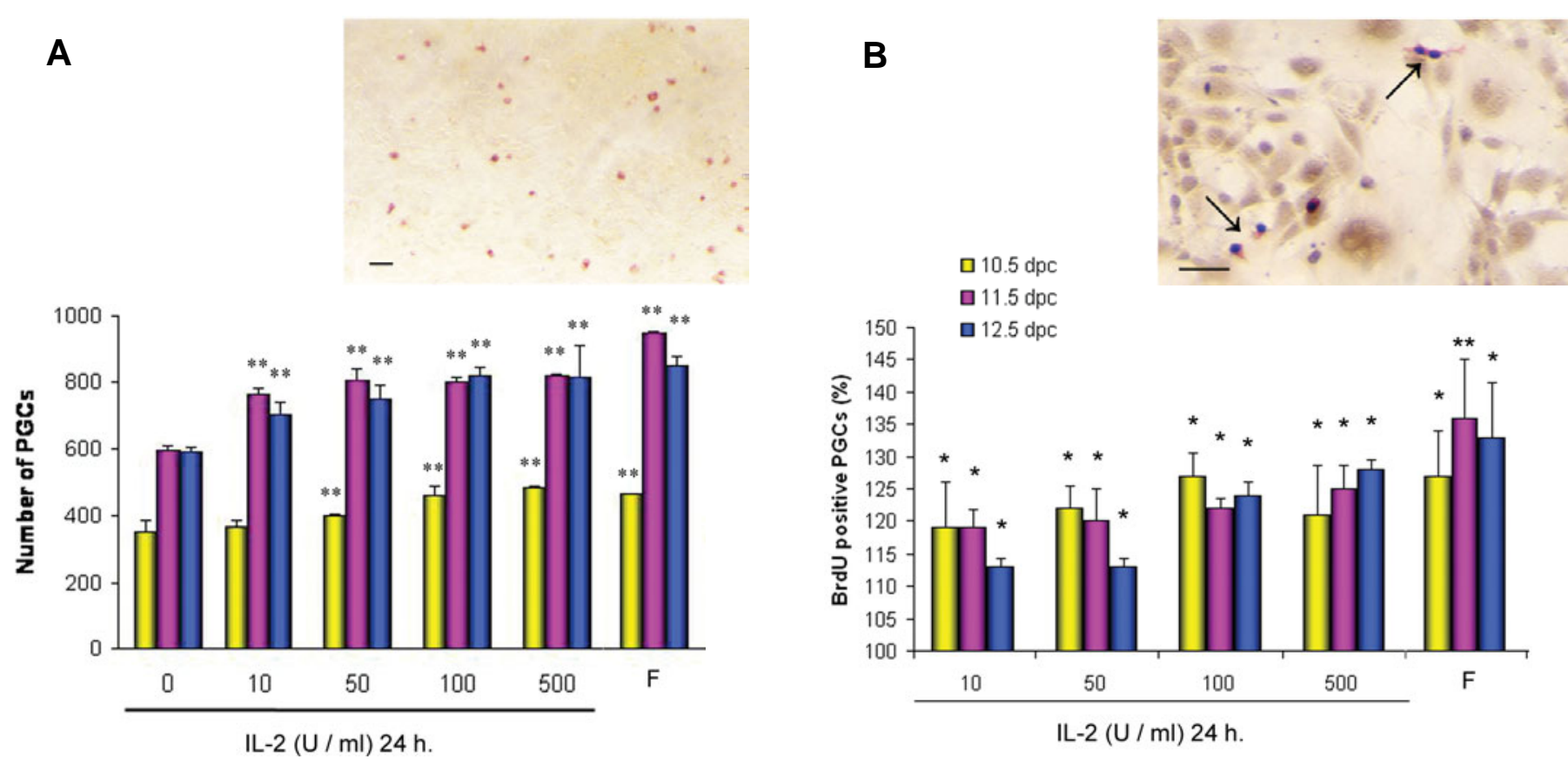

Fig. 3. Effect of IL-2 on PGC proliferation. (A) The effect of various doses of mouse recombinant IL-2 on the number of PGCs, measured as alkaline phosphatase (AP) positive cells, isolated from 10.5, 11.5 and $12.5 \mathrm{dpc}$ embryos, cultured on STO feeder cells and treated for $24 \mathrm{~h}$. Bars represent the mean number of PGCs per well plus standard deviation of three replicate wells. After 24 hours, $1 \mathrm{~L}-2 \mathrm{Lt} 10 \mathrm{U} / \mathrm{m} /$ showed a significant proliferative effect in 11.5 and $12.5 \mathrm{dpc} P G C s$, but not in $10.5 \mathrm{dpc}(p<0.01)$. Nevertheless, at doses of 50,100 and $500 \mathrm{U} / \mathrm{ml}$, IL-2 did significantly increase the number of PGCs from 10.5, 11.5 and $12.5 \mathrm{dpc}$ embryos ( $\mathrm{p}<0.01$ ). The illustration shows a culture of $10.5 \mathrm{dpc} P G C s$ treated for $24 \mathrm{~h}$ with $\mathrm{IL}-2$ (500 $\mathrm{U} / \mathrm{ml}$ ) on STO feeder cells and stained for AP (Bar, $100 \mu \mathrm{m})$. (B) Proportion (\%) of BrdU-labeled cells with respect to the total number of AP positive cells, taking as control (100\%) the number of double-stained cells obtained in non-treated cultures. PGCs isolated from 10.5, 11.5 and 12.5 dpc embryos were cultured for 1 day as above and treated with the indicated doses of IL-2 for $24 \mathrm{~h}$. Subsequently, they were labeled with BrdU and histochemically doublestained for BrdU and AP. The increase in proliferation was around $12-25 \%$ in all the PGC cultures. The forskolin (F) control produced a proliferative effect between 25-35\% in PGCs from 10.5, 11.5 and $12.5 \mathrm{dpc}$ embryos. (*) Significant at $P<0.05 ;{ }^{* *}$ ) significant at $P<0.01$. The illustration to the right shows a culture of PGCs after BrdU incorporation assay plus $\mathrm{IL-2}(500 \mathrm{U} / \mathrm{ml})$ treatment. Black arrows point to proliferating PGCs, which are double stained for BrdU and AP (Bar, $50 \mu \mathrm{m})$.

melanoma cells (Boyano et al., 1998; García Vazquez et al., 2000) also express this cytokine and its receptor. In the present study, expression of the IL-2, IL-2R $\alpha$ and IL-2R $\beta$ genes was analyzed by RT-PCR using total RNA purified from PGC and somatic cell samples with a purity higher than $90 \%$ (Fig. 1). The PCR products were then subjected to electrophoresis and IL-2R $\alpha$ and IL-2R $\beta$ subunit bands were detected in the lanes corresponding to PGCs and somatic cells from 10.5, 11.5 and $12.5 \mathrm{dpc}$ embryos, spermatogonia stem cells and testicular somatic cells. IL-2R $\beta$ mRNA was also detected in the STO mouse embryonic fibroblast cell line. However, IL-2 expression was not observed in any of the analyzed samples. Expression of IL-2R $\gamma$ was not examined by PCR since its presence in PGCs has been previously reported (Cooke et al., 1996).

To verify the expression of IL-2R subunit peptides ( $\alpha, \beta$ and $\gamma$ ) on the surface of PGCs, indirect immunofluorescence assays were performed using confocal microscopy. IL-2R $\alpha$ (Fig. 2A), IL$2 \mathrm{R} \beta$ (Fig. 2B) and IL-2R $\gamma$ (Fig. 2C) peptides were found to be expressed on the surface of PGCs at $11.5 \mathrm{dpc}$. As a negative control, we omitted the primary antibody during the immunocytochemical procedure, which led to the absence of immunofluorescence (Fig. 2D). Thus, we show that PGCs might be a target of the IL- 2 cytokine since $\alpha, \beta$ and $\gamma$ chains of the IL-2R were found to be expressed in isolated PGCs from 10.5, 11.5 and $12.5 \mathrm{dpc}$ embryos, at mRNA and protein levels. We also show that the $\alpha$ and $\beta$ subunits of the IL-2R are still expressed in postnatal spermatogonia (Fig. 1).

\section{Effects of IL-2 and IL-2R blockade on PGC proliferation}

PGCs at 10.5, 11.5 and $12.5 \mathrm{dpc}$ were cultured on STO fibroblast feeder layers in the presence of $15 \%$ FCS and treated with IL-2 at $0,10,50,100$ and $500 \mathrm{U} / \mathrm{ml}$ for 24 hours. Each treatment was performed in triplicate and alkaline phosphatase quantification experiments were repeated three times. The mean values associated with the three experiments are illustrated in Fig. 3A. IL-2 did not exhibit any effect on $10.5 \mathrm{dpc}$ PGCs at $10 \mathrm{U} /$ $\mathrm{ml}$ after 24 hours, but a significant proliferative effect was observed in 11.5 and $12.5 \mathrm{dpc}$ PGCs $(p<0.01)$. Nevertheless, at doses of 50,100 and $500 \mathrm{U} / \mathrm{ml}$, IL-2 did significantly increase the number of PGCs from $10.5,11.5$ and $12.5 \mathrm{dpc}$ embryos $(\mathrm{p}<0.01)$. As a positive control, PGCs from the same experiments were cultured in the presence of forskolin at $10 \mu \mathrm{M}$ for 24 hours and the proliferative effect was found to be quite similar to that of IL-2. This result indicates that IL-2 may act as a paracrine or endocrine growth factor for mouse PGCs.

Male PGCs start to undergo mitotic arrest normally at $12.5 \mathrm{dpc}$ 
Fig. 4. Inhibition of IL-2 mediated proliferation of PGCs using antiIL-2R $\alpha$, anti-IL-2R $\beta$ and anti-IL2Ry blocking antibodies, either alone or in combination. $11.5 \mathrm{dpc}$ PGCs were incubated with blocking antibodies for $2 h$ and subsequently with $500 \mathrm{U} / \mathrm{ml}$ of recombinant IL-2 for 24 hours. The number of PGCs was determined by counting AP positive cells. Blockade of the different subunits had no significant effect on the PGC numbers

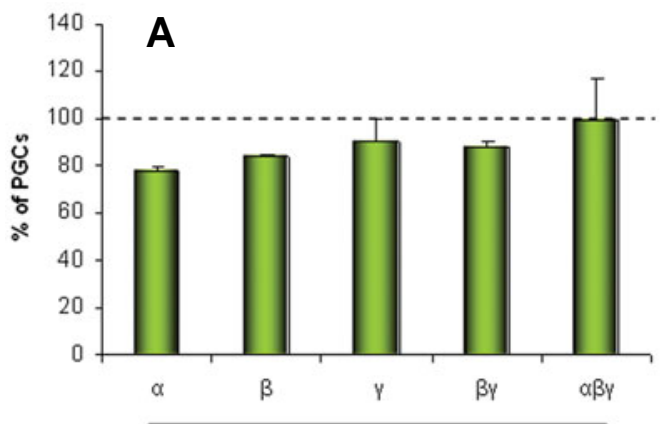

without IL-2

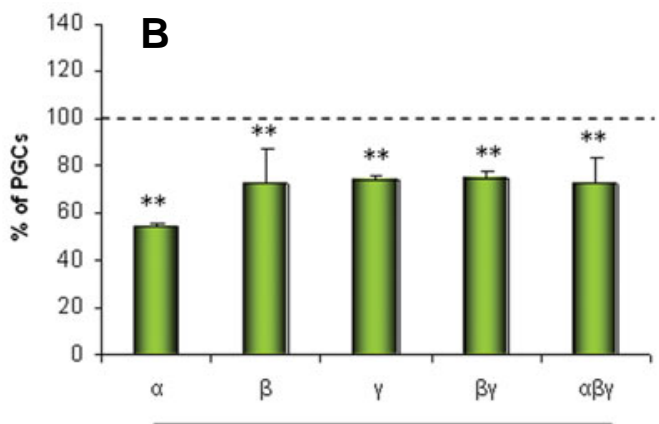

IL-2 (500 U/ml) in untreated cultures (A) while in IL2 treated cultures the blocking antibodies reduced very significantly (up to $45 \% ;{ }^{*}=p<0.01$ ) the number of PGCs compared with IL-2 treated cultures without blocking antibodies (dotted line) (B). The data represent the mean \pm SD of triplicate cultures from three separate experiments.

but, curiously enough, $12.5 \mathrm{dpc}$ and $11.5 \mathrm{dpc}$ PGCs show a very similar response to IL-2. Moreover, these cells are the only ones that significantly increase their proliferation rate at the lower IL-2 concentration $(10 \mathrm{U} / \mathrm{ml})$, suggesting that they express more IL-2 receptor than $10.5 \mathrm{dpc}$ cells, or that their IL-2 receptor is more sensitive or more efficiently coupled to second messenger cascades. This finding opens up the possibility that IL-2 could delay or even revert the mitotic arrest which occurs in $12.5 \mathrm{dpc}$ male PGCs. Indeed, IL-2 mediated reversion of mitotic arrest may constitute one component of the pathological progression of embryonal carcinoma of the gonads (Diez-Torre et al., 2004).

Bromodeoxyuridine (BrdU) incorporation assays were performed in order to examine if IL-2 was acting as a mitogen or a survival factor in this cell population. In these experiments PGCs from 10.5, 11.5 and $12.5 \mathrm{dpc}$ embryos were double-stained for BrdU incorporation and alkaline phosphatase activity (Fig. 3B). We found that there were changes in the proportion of BrdU positive cells in 10.5, 11.5 and $12.5 \mathrm{dpc}$ PGCs treated with IL-2 at all doses. Increase in proliferation was around 12- $25 \%$ in PGCs from 10.5 to $12.5 \mathrm{dpc}$ embryos with respect to the BrdU positive PGCs in untreated cultures (control, considered as 100\%). The forskolin control $(10 \mu \mathrm{M})$ produced a proliferative effect of around 25-35\% in PGCs from 10.5, 11.5 and 12.5 dpc embryos. These assays reveal that the increase in number of PGCs in culture after treatment with IL-2 was due to a mitogenic rather than a survival effect. This IL-2 effect is different to that of other interleukins, such as IL-4, IL-6 and IL-11, which only exert a survival effect (De Felici and Dolci., 1991; Cooke etal., 1996; Cheng etal., 1994; Koshimizu et al., 1996). However, it coincides with the proliferative effect of IL-2 on T lymphocytes (Cornish et al., 2006).

We neutralized IL-2 receptor subunits with anti-IL-2R $\alpha, \beta$ and $\gamma$ blocking antibodies, independently or as a combination of subunit blockers, for 2 hours and then the cells were incubated in the presence or absence of $500 \mathrm{U} / \mathrm{ml} \mathrm{IL-2} \mathrm{for} 24$ hours (Fig. 4). We found that blocking the IL-2R $\alpha, \beta$ and $\gamma$ subunits independently or as combinations of $\beta \gamma$ or $\alpha \beta \gamma$ subunit blockers did not have a significant effect on PGC proliferation rate (Fig. 4A). However, under the same conditions but in the presence of IL-2, a significant inhibition of PGC proliferation was observed (Fig. 4B). The percentage of inhibition was $45 \%$ when the $\alpha$ subunit was neutralized, while other blockades led to an inhibition of about $30 \%$ compared with those cultures treated with $500 \mathrm{U} / \mathrm{ml} \mathrm{IL-2}$ in the absence of blocking antibodies. These results demonstrate that this effect is specifically mediated by the IL-2R, since blockade of any of its subunits with subunit-specific antibodies abrogated the IL-2 mitogenic effect on PGC cultures.

Finally, we compared the proliferative effect of IL-2 with other cytokines which are known mitogen and/or survival factors such as bFGF (mitogen), LIF (survival factor) and SF (mitogen + survival factor). We cultured PGCs at $11.5 \mathrm{dpc}$ on STO feeder layers in the presence of $15 \%$ FCS, supplemented with IL-2 (500 $\mathrm{U} / \mathrm{ml}), \mathrm{bFGF}(10 \mathrm{ng} / \mathrm{ml})$, SF $(20 \mathrm{ng} / \mathrm{ml})$ or LIF $(10 \mathrm{ng} / \mathrm{ml})$ for 24 hours. We found that the proliferative effect of IL-2 was very similar to that of bFGF, SF and LIF in PGCs from $11.5 \mathrm{dpc}$ embryos $(p<0.05)$ (Fig. 5), supporting the idea that IL-2 plays a physiologically relevant role in the regulation of the PGC population at this developmental stage. Since a variety of growth factors and cytokines increase PGC numbers in vitro, as mentioned before, the lack of one of them would not necessarily have a significant effect on germ line development, because its function could be replaced by other factors (factor redundancy). In fact, transgenic mice with deletion of the $\gamma$ subunit of the IL-2R (necessary for IL-2 signal transduction) do not show any significant alteration of their gonads (DiSanto et al., 1995).

\section{Common role of the IL-2/IL-2R system in PGC and HSC development}

A possible physiological role for IL-2 in PGCs in vivo is supported by the presence of this cytokine in the embryo in places where PGC migration and proliferation take place. Expression of IL-2 in vivo has been shown in several tissues such as the decidua, placenta (von Rango et al., 2003) and embryonic liver, thymus, pharyngeal blood vessels and omentum (Godin et al., 1995; Reya et al., 1996). The expression of IL-2 and its receptors in various tissues of the postimplanted embryo was found to be associated with the location of HSCs and their differentiation into extrathymic T cells during development (Murray et al., 1998). IL2 is also expressed by HSCs which spatially coincide with PGCs in early embryos (Zeigler et al., 2006). In addition, it is already well known that the embryo receives maternal growth factors through the placenta (McLennan and Koishi, 2004), raising the possibility that maternal IL-2 could also have a role in PGC development.

Our findings of a functional IL2/IL2R system for PGC proliferation show another similarity between HSCs and PGCs, supporting 
the hypothesis of a common stem cell precursor or, at least, a close developmental pathway for these two cell lineages. Genetic studies have shown that the development of hematopoietic cells parallels that of germ cells. Natural mutations at the Wand Stee/ loci, encoding the tyrosine kinase receptor c-Kit and its SF ligand (also known as SCF, MGF or $\mathrm{KL}$ ), respectively, determine a phenotype causing embryonic death at 14-15 dpc due to anemia. $W / W$ and $S / / S /$ embryos also lack germ cells and melanoblasts (for a review see Besmer, 1991). SF exerts pleiotropic effects on PGC and hematopoietic cell proliferation and survival (Matsui et al., 1991, Godin et al., 1991; Dolci etal., 1991, Carson etal., 1994) and both PGCs and HSCs adhere to somatic cells by expressing the membrane-bound variant of SF (Pesce etal., 1997; Bendall et al., 1998). The enhanced SF-mediated survival of germ and hematopoietic cells in vitro is probably due to the suppression of similar apoptotic pathways, which involve the control of expression of Bcl-2 and Bax (Pesce et al., 1993; Carson et al., 1994; De Felici et al., 1999). During mouse embryogenesis, restriction of hematopoietic potential to cells of the posterior part of the epiblast is established. Before gastrulation, all epiblastic cells are equally able to enter the hematopoietic lineage while, as gastrulation proceeds, this ability is confined to the extraembryonic mesodermal compartment, where progenitors of HSCs and PGCs are allocated (Kanatsu and Nishikawa, 1996; Lawson and Hage, 1994). Interestingly, stimulation of anterior epiblastic cells of gastrula stage embryos with secreted Bmp-4 inhibits their differentiation pathway as neuroectodermal cells and restores their ability to form hematopoietic colonies (Kanatsu and Nishikawa, 1996). Moreover, ablation of Bmp-4 by homologous recombination impairs the formation of the extraembryonic mesodermal compartment (Winnier et al., 1995) and affects, dose-dependently, the segregation of the PGC founder population and hematopoietic precursors (Lawson et al., 1999; McLaren, 1999;

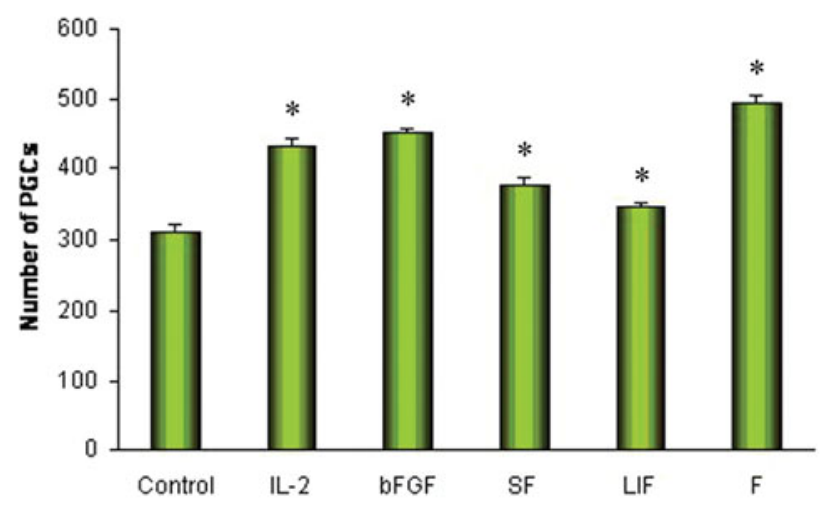

Fig. 5. Comparison of the effects of IL-2 and other growth factors on PGC proliferation. $11.5 d p c$ PGCs were cultured on STO feeder layers in the presence of $15 \%$ FCS, supplemented with $/ L-2(500 \mathrm{U} / \mathrm{ml}), b F G F$ $(10 \mathrm{ng} / \mathrm{ml})$, SF $(20 \mathrm{ng} / \mathrm{ml})$, LIF $(10 \mathrm{ng} / \mathrm{ml})$ or forskolin $(F, 10 \mu \mathrm{M})$ for 48 hours. The number of PGCs was determined by counting AP positive cells. The graph shows that the proliferative effect of IL-2 was very similar to that of bFGF and forskolin in PGCs from $11.5 \mathrm{dpc}$ embryos $(p<0.05)$. The effect of SF and LIF was always proliferative with respect to the control $(p<0.05)$, but the effect of these cytokines was smaller than that of $I L-2$. The data represent the mean $\pm S D$ of triplicate cultures from three separate experiments. $\left(^{*}\right)$ Significant difference at $p<0.05$.
Fujiwara et al., 2001). Mutation of the $\beta 1$-integrin gene causes a hematopoiesis defect in fetal liver but not in yolk sac (Fassler and Meyer, 1995). This suggests that mechanisms of cell adhesion/ migration are involved in the allocation of a precursor of HSCs in the aorta-gonadomesonephros (AGM) before they enter into the dorsal aorta. Similar integrin-mediated adhesion mechanisms have been also suggested for PGCs (De Felici and Dolci, 1989; French-Constant et al., 1991). In line with these arguments, it has been shown that mice defective for $\beta 1$-integrin also exhibit an impaired migration of PGCs towards the AGM region and gonadal ridges (Anderson et al., 1999). Moreover, HSCs and PGCs appear to share homing mechanisms mediated by SDF-1 and its receptor CXCR4. In fact, mice lacking either SDF-1 or CXCR4 have impaired colonization of bone marrow and gonads (Ma etal., 1998; Ara et al., 2003).

In summary, we provide evidence that PGCs express functional IL-2 receptors during their migration to and colonization of gonadal ridges and that the IL-2 cytokine increases the in vitro proliferation of PGCs through a mitogenic, rather than survival, effect. Thus, these results support the hypothesis that the IL-2/IL$2 \mathrm{R}$ system may be involved in the proliferation and differentiation of PGCs in mouse embryos, in a manner similar to that which occurs in embryonic hematopoiesis.

\section{Experimental Procedures}

\section{Isolation and culture of mouse PGCs}

PGCs were isolated and purified from the gonadal ridges of mouse embryos at 10.5, 11.5 and $12.5 \mathrm{dpc}$ using the Mini-Macs system (Pesce and De Felici, 1995). They were then cultured on mitomycin C inactivated STO fibroblast monolayers in DMEM. The medium was supplemented with $15 \%$ FCS, N-acetyl-cysteine (Sigma, St. Louis, MO, USA), sodium pyruvate (Sigma, St. Louis, MO, USA) and cells were seeded (about 1 gonadal ridge equivalent/well) in 24-well culture plates. The purity of the obtained PGC samples was higher than $90 \%$ as determined by PGCspecific alkaline phosphatase staining.

\section{Isolation of spermatogonia cells}

Spermatogonia were obtained from 6-7 day-old mice testes. Decapsulated testes were digested with collagenase-II (Sigma, St. Louis, MO, USA). Seminiferous tubuli were isolated after centrifugation at $85 \mathrm{~g}$ for 7 minutes and subsequently digested with a trypsin-EDTA salt solution (Invitrogen Life Technologies, Carlsbad, CA) and DNase-I (Sigma, St. Louis, MO, USA). The obtained cell suspension was filtered using a nylon net (Falcon; BD Biosciences, Heidelberg, Germany) to remove cell aggregates and was centrifuged at $390 \mathrm{~g}$ for $10 \mathrm{~min}$. In order to separate spermatogonia from somatic cells, cell suspensions were plated into culture flasks and maintained at $32^{\circ} \mathrm{C}$ overnight in DMEM supplemented with $10 \%$ FCS, $32 \mathrm{mM} \mathrm{NaHCO} 3,2 \mathrm{mM}$ glutamine, $100 \mathrm{U} / \mathrm{ml}$ penicillin and $100 \mu \mathrm{g} / \mathrm{ml}$ streptomycin (Sigma, St. Louis, MO, USA). Spermatogonia (which remained in suspension) and somatic cells (which adhered to the substrate) were collected separately and washed before experiments. Cell suspensions were incubated with anti-vimentin-FITC in order to analyze spermatogonia and somatic cell sample purity by flow cytometry analysis. Spermatogonia were identified as vimentin-negative cells, while testicular somatic cells were vimentin positive (data not shown). Only those samples with a purity over $90 \%$ were used for experiments.

\section{Other Cells}

The STO mouse embryonic fibroblast cell line (European Collection of Cell Cultures, Salisbury, UK) was cultured with DMEM supplemented with $10 \%$ FCS, $32 \mathrm{mM} \mathrm{NaHCO}$, $2 \mathrm{mM}$ glutamine, $100 \mathrm{U} / \mathrm{ml}$ penicillin and 100 
$\mu \mathrm{g} / \mathrm{ml}$ streptomycin (Sigma, St. Louis, MO, USA). Murine splenic mononuclear cells were used as positive controls for IL-2/IL-2R expression. These cells were isolated, activated and cultured as previously described (Boyano et al., 1998).

\section{Reverse-transcription and PCR}

Total RNA from PGCs, gonadal ridges and testicular somatic cells, spermatogonia, mouse embryonic fibroblasts STO and activated mononuclear cells was purified using the RNeasy Mini Kit (Qiagen, Hilden, Germany). Reverse-transcription was performed using the RETROscript kit (Ambion, Austin, TX, USA). PCR was achieved with the Platinum PCR Supermix (Invitrogen Life Technologies, Carlsbad, CA), according with the manufacturer's instructions. Mouse specific primers for PCR amplification were purchased from Invitrogen. Their sequences and annealing temperatures are summarized in Table 1. Annealing temperature ranged between 55 and $61^{\circ} \mathrm{C}$ for all primers. PCR products were subjected to electrophoresis in $2 \%$ agarose gels containing ethidium bromide (Merck, Darmstadt, Germany) in TBE $1 \mathrm{X}$ buffer and subsequently visualized under UV illumination (LKB Bromma 2011 macrovue).

RNA from $12.5 \mathrm{dpc}$ embryo fetal liver was used as positive control for $\beta$-actin gene expression. RNA from murine splenic mononuclear cells, activated with phytohemagglutinin-M (Roche, Mannheim, Germany) was used as positive control for the presence of IL-2, IL-2R $\alpha$ and IL-2R $\beta$ mRNA. A negative control containing water instead of cDNA was included in PCR experiments.

\section{Immunofluorescence assays}

PGCs were seeded onto chamber slides (Nunc, Naperville, USA) and fixed in $4 \%$ paraformaldehyde after 4 hours of culture. Cells were washed three times in phosphate buffered saline (PBS) and blocked with $10 \%$ FCS in PBS, before incubation with the primary antibody for 60 min at room temperature in 5\% FCS in PBS. Specific rat antibodies were antimouse IL-2R $\alpha(2 \mu \mathrm{g} / \mathrm{ml})$ and anti-mouse IL-2R $\beta(1 \mu \mathrm{g} / \mathrm{ml})$, both from Santa Cruz Biotechnology Inc. (Santa Cruz, CA, USA) and anti-mouse IL-2R $\gamma(1 \mu \mathrm{g} / \mathrm{ml})$ from BD Biosciences, (Heidelberg, Germany). After three washes in PBS, cells were incubated with FITC-conjugated anti-rat $\operatorname{lgG}(30 \mu \mathrm{g} / \mathrm{ml})$ (Sigma, St. Louis, MO, USA) in the same buffer as that used for the primary antibody for $60 \mathrm{~min}$ in the dark. Stained cells were washed with PBS containing $0.4 \mu \mathrm{g} / \mathrm{ml}$ 4',6-diamin-2-phenylindoldihydrochloride (DAPI) and mounted onto Fluoromount $G$ mounting medium (Electron Microscopy Sciences, Washington D.C., USA). Cells were examined with an Olympus Fluoview 500 confocal microscope.

\section{Proliferation assays and neutralization}

PGCs were seeded into 24-well microplates at an approximate concentration of one gonadal ridge equivalent/well on mitomycin-C inactivated STO cell monolayers in serum-containing medium with different concentrations of recombinant IL-2 (0, 10, 50, 100 and $500 \mathrm{U} /$ $\mathrm{ml}$ ) (Roche, Mannheim, Germany). bFGF (10 ng/ml, R\&D systems), SF (20 ng/ml, R\&D Systems), LIF (10 ng/ml) or forskolin (10 $\mu \mathrm{M}$, Sigma) were used as a positive control in these experiments. LIF was isolated as described by Gearing et al., 1989. Cells were cultured for 24 hours and their proliferation was determined by counting the number of alkaline phosphatase stained cells and expressing this as a percentage of control (cells incubated without IL-2). Proliferation was also quantified by counting alkaline phosphatase stained cells which exhibited nuclear incorporation of bromodeoxyuridine (BrdU) using the Amersham cell proliferation kit (RPN20) as previously described (De Felici and Dolci, 1989). Briefly, the cells were fixed after 2 hours of BrdU labeling and then PGCs were double-stained for alkaline phosphatase activity and BrdU incorporation. Each concentration of IL-2 was applied to three wells, and the experiment was repeated three times. For neutralization assays, PGCs were cultured on STO cell feeder layers for 2 hours without FCS in the presence of anti-mouse IL-2R $\alpha(2 \mu \mathrm{g} / \mathrm{ml})$, anti-mouse IL-2R $\beta(1 \mu \mathrm{g} / \mathrm{ml})$

\section{TABLE 1}

\section{PRIMERS SEQUENCES USED FOR RT-PCR}

\begin{tabular}{|c|c|c|c|}
\hline rimer & Sequence & Amplicon size (bp) & T annealing: ${ }^{\circ} \mathrm{C}$ \\
\hline \multirow{2}{*}{-2} & F: 5'-ATGTACAGCATGCAGCTCGCATC -3' & 502 & 55 \\
\hline & R: 5'-GGCTTGTTGAGATGATGCTTTGACA -3' & & \\
\hline \multirow[t]{2}{*}{$-2 R \alpha$} & F: 5'-ATGGAGCCACGCTTGCTGATGTTG -3' & 700 & 55 \\
\hline & R: 5'-CCATTGTGAGCACAAATGTCTCCG -3' & & \\
\hline \multirow[t]{2}{*}{$-2 R \beta$} & F: 5'-CTCCGTGGACCTCCTTGACATAAATGTGG -3' & 348 & 58 \\
\hline & R: 5' - TGTTTCGTTGAGCTTTGACCCTCACCTGG -3 & & \\
\hline \multirow[t]{2}{*}{-actin } & F: 5'-GTGGGCCGCTCTAGGCACCAA -3' & 540 & 55 \\
\hline & R: 5'-CTCTTTGATGTCACGCACGATTTC -3' & & \\
\hline
\end{tabular}

(Santa Cruz Biotechnology, Inc., Santa Cruz, CA), and anti-mouse IL-2Ry $(1 \mu \mathrm{g} / \mathrm{ml})$ (BD Biosciences, Heidelberg, Germany). Then, they were incubated for 24 hours in the presence or absence of recombinant IL-2 $(500 \mathrm{U} / \mathrm{ml})$. Cell growth was determined by proliferation assays with alkaline phosphatase staining in microplates as described above. Proliferation was expressed as the percentage of PGCs with respect to the number of PGCs in similar conditions but in the absence of subunit antibodies ( $n=3$ independent experiments).

\section{Statistics}

Values are expressed as means + standard deviation $(n=3)$. Significance was defined as $\mathrm{p}<0.05\left({ }^{*}\right)$ and $\mathrm{p}<0.01\left(^{* *}\right)$. Statistical analyses were performed using the ANOVA test with SPSS 12.0 for Windows.

\section{Acknowledgements}

This work was supported by the University of the Basque Country (grant 9/UPV00077.327-15304), the Spanish Ministry of Education and Science (grant BFU2007-66610/BFl and a predoctoral fellowship for CE) and the Jesús de Gangoiti Barrera Foundation (postdoctoral fellowship for $A D T$ ).

\section{References}

ANDERSON, R., FÄSSLER, R., GEORGES-LABOUESSE, E., HYNES, R.O., BADER, B.L., KREIDBERG, J.A., SCHAIBLE, K., HEASMAN, J. and WYLIE C. (1999). Mouse primordial germ cells lacking beta1 integrins enter the germline but fail to migrate normally to the gonads. Development 126: 1655-1664.

ARA, T., NAKAMURA, Y., EGAWA, T., SUGIYAMA, T., ABE, K., KISHIMOTO, T., MATSUI, Y. and NAGASAWA, T. (2003). Impaired colonization of the gonads by primordial germ cells in mice lacking a chemokine, stromal cell-derived factor-1 (SDF-1). Proc. Natl. Acad. Sci. USA. 100: 5319-5323.

ASAO, H., OKUYAMA, C., KUMAKI, S., ISHII, N., TSUCHIYA, S., FOSTER, D. and SUGAMURA, K. (2001). Cutting edge: the common gamma-chain is an indispensable subunit of the IL-21 receptor complex. J. Immunol. 167: 1-5.

BENDALL, L.J., MAKRYNIKOLA, V., HUTCHINSON, A., BIANCHI, A.C., BRADSTOCK, K.F. and GOTTLIEB, D.J. (1998). Stem cell factor enhances the adhesion of AML cells to fibronectin and augments fibronectin-mediated antiapoptotic and proliferative signals. Leukemia 12: 1375-1382.

BESMER, P. (1991). The kit ligand encoded at the murine Steel locus: a pleiotropic growth and differentiation factor. Curr. Opin. Cell Biol. 3: 939-946.

BOYANO, M.D., GARCíA DE GALDEANO, A., GARCíA-VAZQUEZ, M.D., ALVAREZ, A. and CAÑAVATE, M.L. (1998). Cyclosporin A upmodulates the alpha-subunit of the interleukin-2 receptor and the metastatic ability of murine B16F10 melanoma cells. Invasion Metastasis. 18: 122-133.

CAIRNS, L.A., MORONI, E., LEVANTINI, E., GIORGETTI, A., KLINGER, F.G., RONZONI, S., TATANGELO, L., TIVERON, C., DE FELICI, M., DOLCI, S. et al. (2003). Kit regulatory elements required for expression in developing hematopoietic and germ cell lineages. Blood. 102: 3954-3962.

CARSON, W.E., HALDAR, S., BAIOCCHI, R.A., CROCE, C.M. and CALIGIURI, M.A. (1994). The C-Kit ligand suppresses apoptosis of human natural killer cells through upregulation of bcl-2. Proc. Natl. Acad. Sci. USA 91: 7553-7557.

CHENG, L., GEARING, D.P., WHITE, L.S., COMPTON, D.L., SCHOOLEY, K. and 
DONOVAN, P.J. (1994). Role of leukemia inhibitory factor and its receptor in mouse primordial germ cell growth. Development. 120: 3145-3153.

COOKE J.E., HEASMAN J. and WYLIE C.C. (1996). The role of interleukin-4 in the regulation of mouse primordial germ cell numbers. Dev. Biol. 174: 14-21.

CORNISH, G.H., SINCLAIR, L.V. and CANTRELL, D.A. (2006). Differential regulation of T-cell growth by IL-2 and IL-15. Blood. 108: 600-608.

DE FELICI, M. and DOLCI, S. (1989). In vitro adhesion of mouse fetal germ cells to extracellular matrix components. Cell Differ. Dev. 26: 87-96

DE FELICI, M. and DOLCI, S. (1991). Leukemia inhibitory factor sustains the survival of mouse primordial germ cells cultured on TM4 feeder layers. Dev. Biol. 147: 281-284.

DE FELICI, M., DI CARLO, A., PESCE, M., IONA, S., FARRACE, M.G. and PIACENTINI, M. (1999). Bcl-2 and Bax regulation of apoptosis in germ cells during prenatal oogenesis in the mouse embryo. Cel/ Death and Differentiation 6: 908-915.

DE FELICI, M., SCALDAFERRI, M. L., LOBASCIO, M., IONA, S., NAZZICONE, V., KLINGER, F.G. and FARINI, D. (2004). Experimental approaches to the study of primordial germ cell lineage and proliferation. Hum. Reprod. Update. 10: 197206.

DIEZ-TORRE, A., SILVÁN, U., DE WEVER, O., BRUYNEEL, E., MAREEL, M. and ARÉCHAGA, J. (2004). Germinal tumor invasion and the role of the testicular stroma. Int. J. Dev. Biol. 48: 453-465

DI SANTO, J.P., KUHN, R. and MULLER, W. (1995). Common cytokine receptor gamma chain (gamma c)-dependent cytokines: understanding in vivo functions by gene targeting. Immunol. Rev. 148: 19-34.

DOLCI, S., WILLIAMS, D.E., ERNST, M.K., RESNICK, J.L., BRANNAN, C.L., LOCK, L.F., LYMAN, S.D., BOSWELL, H.S. and DONOVAN, P.J. (1991). Requirement for mast cell growth factor for primordial germ cell survival in culture. Nature. 352: 809-811.

FASSLER, R. and MEYER, M. (1995). Consequences of lack of beta 1 integrin gene expression in mice. Genes Dev. 9: 1896-1908.

FRENCH-CONSTANT, C., HOLLINGSWORTH, A, HEASMAN, J. and WYLIE, C.C. (1991). Response to fibronectin of mouse primordial germ cells before, during and after migration. Development 113: 1365-1373.

FUJIWARA, T., DUNN, N. R. and HOGAN, B.L.M. (2001). Bone morphogenetic protein 4 in the extraembryonic mesoderm is required for allantois development and the localization and survival of primordial germ cells in the mouse. Proc. Natl. Acad. Sci. USA 98: 13739-13744.

GAFFEN, S.L. and LIU, K.D. (2004). Overview of interleukin-2 function, production and clinical applications. Cytokine. 28: 109-123.

GARCIA-VAZQUEZ, M.D., BOYANO, M.D., CAÑAVATE, M.L., GARDEAZABAL, J., DE GALDEANO, A.G., LOPEZ-MICHELENA, T., RATON, J.A., IZU, R., DIAZ-RAMON, J.L. and DIAZ-PEREZ, J.L. (2000). Interleukin- 2 enhances the growth of human melanoma cells derived form primary but not from metastatic tumours. Eur. Cytokine Netw. 11: 654-661.

GEARING, D.P., NICOLA, N.A., METCALF, D., FOOTE, S., WILLSON, T.A., GOUGH, N.M. and WILLIAMS, R.L. (1989). Production of leukemia inhibitory factor in Escherichia Coli by a novel procedure and its use maintaining embryonic stem cells in culture. Biotechnology. 7: 1157-1161.

GIRI, J.G., AHDIEH, M., EISENMAN, J., SHANEBECK, K., GRABSTEIN, K., KUMAKI, S., NAMEN, A., PARK, L.S., COSMAN, D. and ANDERSON, D. (1994). Utilization of the beta and gamma chains of the IL- 2 receptor by novel cytokine IL-15. EMBO J. 13: 2822-2830.

GODIN, I., DEED, R., COOKE, J., ZSEBO, K., DEXTER, M. and WYLIE, C.C. (1991). Effects of the steel gene product on mouse primordial germ cells in culture. Nature. 352: 807-809.

GODIN, I., DIETERLEN-LIEVRE, F. and CUMANO, A. (1995). B-lymphoid potential in pre-liver mouse embryo. Semin. Immunol. 7: 131-141.

GODIN, I. and WYLIE, C.C. (1991). TGFbeta1 inhibits proliferation and has a chemotropic effect on mouse primordial germ cells in culture. Development. 113: $1451-1457$.

GRANUCCI, F., VIZARDELLI, C., PAVELKA, N., FEAU, S., PERSico, M. and VIRZI, E. (2001). Inducible IL-2 production by dendritic cells revealed by global gene expression analysis. Nature Immunol. 2: 882-888.

HE, Y.W. and MALEK, T.R. (1995). The IL-2 receptor gamma c-chain does not function as a subunit shared by the IL- 4 and the IL-13 receptors. Implications for the structure of the IL-4 receptor. J. Immunol. 155: 9-12.

KANATSU, M. and NISHIKAWA, S.I. (1996). In vitro analysis of epiblast tissue potency for hematopoietic cell differentiation. Development 122: 823-830.

KIM, H.P., IMBERT, J. and LEONARD, W.J. (2006). Both integrated and differential regulation of components of the IL-2/L-2 receptor system. Cytokine Growth Factor Rev. 17: 349-366.

KOSHIMIZU, U., TAGA, T., WATANABE, M., SAITO, M., SHIRAYOSHI, Y. KISHIMOTO, T. and NAKATSUJI, N. (1996). Functional requirement of gp-130mediated signaling for growth and survival of mouse primordial germ cells in vitro and derivation of embryonic germ (EG) cells. Development. 122: 12351242.

LAWSON, K.A. and HAGE, W. J. (1994). Clonal analysis of the origin of primordial germ cells in the mouse. In Germline Development (Eds. J. Marsh and J. Goode). Ciba Foundation Symposium 182, pp. 68-91.

LAWSON, K.A., DUNN, N.R., ROELEN, B.A., ZEINSTRA, L.M., DAVIS, A.M. WRIGHT, C.V., KOLEWING, J.P. and HOGAN, B.L.M. (1999). Bmp4 is required for the generation of primordial germ cell in the mouse embryo. Genes Dev. 13 : 424.436.

LEONARD, W.J., DEPPER, J.M., CRABTREE, G.R., RUDIKOFF, S., PUMPHREY, J., ROBB, R.J., KRONKE, M., SVETLIK, P.B., PEFFER, N.J., WALDMANN, T.A., et al. (1984). Molecular cloning and expression of CDNAs for the human interleukin-2 receptor. Nature. 311: 626-631.

MA, Q., JONES, D, BORGHESANI, P.R., SEGAL, R.A., NAGASAWA, T. KISHIMOTO, T., BRONSON, R.T. and SPRINGER, T.A. (1998). Impaired Blymphopoiesis, myelopoiesis and derailed cerebellar neuron migration in CXCR4and SDF-1-deficient mice. Proc. Natl. Acad. Sci. USA 95: 9448-9453.

MATSUI, Y., TOKSOZ, D., NISHIKAWA, S., NISHIKAWA, S-I., WILLIAMS, D. ZSEBO, K. and HOGAN B.L. (1991). Effect to steel factor and leukemia inhibitory factor on murine primordial germ cells in culture. Nature. 353: 750752.

MCLAREN, A. (1999). Signaling for germ cells. Genes Dev. 13: 373-376.

MCLAREN, A. (2003). Primordial germ cells in the mouse. Dev. Biol. 262: 1-15.

MCLENNAN, I.S. and KOISHI, K. (2004). Fetal and maternal transforming growth factor-beta 1 may combine to maintain pregnancy in mice. Biol. Reprod. 70: 1614-1618.

MOLYNEAUX, K. and WYLIE, C. (2004). Primordial germ cell migration. Int. J. Dev. Biol. 48: 537-544.

MURRAY, A.M., SIMM, B. and BEAGLEY, K.W. (1998). Cytokine gene expression in murine fetal intestine: potential for extrathymic T cell development. Cytokine. 10: 337-345.

NOGUCHI, M., NAKAMURA, Y., RUSSELL, S.M., ZIEGLER, S.F., TSANG, M. CAO, X. and LEONARD, W.J. (1993). Interleukin-2 receptor gamma chain: a functional component of the interleukin-7 receptor. Science. 262: 1877-1880.

OTHAKA, T., MATSUI,Y. and OBINATA, M. (1999). Hematopoietic development of primordial germ cell derived mouse embryonic germ cells in coculture. Biochem. Biophys. Res. Commun. 260: 475- 482.

PESCE, M., DI CARLO, A. and DE FELICI, M. (1997). The c-kit receptor is involved in the adhesion of mouse primordial germ cells to somatic cells in culture. Mech. Dev. 68: 37-44.

PESCE, M. and DE FELICI, M. (1995). Purification of mouse primordial germ cells by MiniMACS magnetic separation system. Dev. Biol. 170: 722-725.

PESCE, M., FARRACE, M.G., PIACENTINI, M., DOLCI, S. and DE FELICI, M. (1993). Stem cell factor and leukemia inhibitory factor promote primordial germ cell survival by suppressing programmed cell death (Apoptosis). Development. 118: 1089-1094

RESNICK, J.L., BIXLER, L.S., CHENG, L. and DONOVAN, P.J. (1992). Long-term proliferation of mouse primordial germ cell in culture. Nature. 359: 550-551.

REYA, T., YANG-SNYDER, J.A., ROTHENBERG, E.V. and CARDING, S.R (1996). Regulated expression and function of CD122 (Interleukin-2/InterleukinI5R-beta) during lymphoid development. Blood. 87: 190-201.

RICH, I.N. (1995). Primordial germ cells are capable of producing cells of the hematopoietic system in vitro. Blood. 86: 463-472.

SUGAMURA, K., ASAO, H., KONDO, M., TANAKA, N., ISHII, N., OHBO, K., NAKAMURA, M. and TAKESHITA, T. (1996). The interleukin-2 receptor gamma 


\section{C. Eguizabal et al.}

chain: its role in the multiple cytokine receptor complexes and T cell development in XSCID. Annu. Rev. Immunol. 13: 179-205.

TAM, P.P. and SNOW, M.H.L. (1981). Proliferation and migration of primordial germ cells during compensatory growth in mouse embryos. J. Embryol. Exp. Morphol. 64: 133-147.

VON RANGO, U., CLASSEN-LINKE, I., RAVEN, G., BOCKEN, F. and BEIER, H. (2003). Cytokine microenvironments in human first trimester decidua are dependent on trophoblast cells. Fertil. Steril. 79: 1176-1186.

WANG, X., RICKERT, M. and GARCIA, K.C. (2005). Structure of the quaternary complex of interleukin-2 with its alpha, beta, and gamma receptors. Science. 310: 1159-1163.

WINNIER, G., BLESSING, M., LABOSKY, P.A. and HOGAN, B.L.M. (1995). Bone morphogenetic protein- 4 is required for mesoderm formation and patterning in the mouse. Genes Dev. 9: 2105-2116.

YODER, M.C. (2001). Introduction: spatial origin of murine hematopoietic stem cells. Blood. 98: 3- 5.

YODER, M.C. (2004). Generation of HSCs in the embryo and assays to detect them. Oncogene. 23: 7161-7163.

ZEIGLER, B.M., SUGIYAMA, D., CHEN, M., GUO, Y., DOWNS, K.M. and SPECK, N.A. (2006). The allantois and chorion, when isolated before circulation or chorio-allantoic fusion, have hematopoietic potential. Development. 133: 41834192.

Published Online: 3rd October 2007 


\section{Related, previously published Int. J. Dev. Biol. articles}

See our Special Issue Mammalian Reproduction \& Development in honor of Anne McLaren and edited by Brigid Hogan at: http://www.ijdb.ehu.es/web/contents.php?vol=45\&issue $=3$

Cloning and pattern of expression of the shiro-uo vasa gene during embryogenesis and its roles in PGC development Akimitsu Miyake, Taiju Saito, Tohru Kashiwagi, Daisuke Ando, Akitsugu Yamamoto, Tohru Suzuki, Norio Nakatsuji and Takako Nakatsuji

Int. J. Dev. Biol. (2006) 50: 619-625

Visualization of primordial germ cells in vivo using GFP-nos1 3'UTR mRNA

Taiju Saito, Takafumi Fujimoto, Shingo Maegawa, Kunio Inoue, Minoru Tanaka, Katsutoshi Arai and Etsuro Yamaha Int. J. Dev. Biol. (2006) 50: 691-700

The formation of primordial germ cells from germline cells in spherical embryos derived from the blastodisc of 2 cell embryos in goldfish, Carassius auratus

Satoshi Otani, Tomoe Kitauchi, Taiju Saito, Suzu Sakao, Shingo Maegawa, Kunio Inoue, Katsutoshi Arai and Etsuro Yamaha Int. J. Dev. Biol. (2005) 49: 843-850

alphallb integrin, a novel marker for hemopoietic progenitor cells

Catherine Corbel Pierre Vaigot and Josselyne Salaün

Int. J. Dev. Biol. (2005) 49: 279-284

Of birds and mice: hematopoietic stem cell development

Isabelle Godin and Ana Cumano

Int. J. Dev. Biol. (2005) 49: 251-257

Commitment of hematopoietic stem cells in avian and mammalian embryos: an ongoing story

Françoise Dieterlen-Lièvre

Int. J. Dev. Biol. (2005) 49: 125-130

Primordial germ cell migration

Kathleen Molyneaux and Christopher Wylie

Int. J. Dev. Biol. (2004) 48: 537-543

Myogenic potential of mouse primordial germ cells. Francesca-Gioia Klinger, Maria-Lucia Scaldaferri, Anna Di Carlo, Marta Baiocchi, Marcello Coletta, Giulio Cossu and Massimo De Felici

Int. J. Dev. Biol. (2003) 47: 303-305

Twenty years of research on primordial germ cells. M De Felici

Int. J. Dev. Biol. (2001) 45: 519-522

Regulation of primordial germ cell development in the mouse.

$M$ De Felici

Int. J. Dev. Biol. (2000) 44: 575-580

Cellular and molecular aspects of mouse primordial germ cell migration and proliferation in culture.

2006 ISI ${ }^{* *}$ Impact Factor $=3.577^{\star *}$

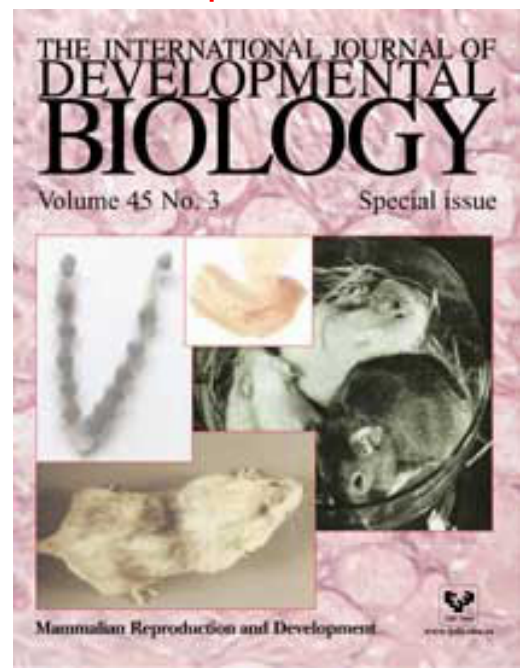

$M$ De Felici, S Dolci and M Pesce

Int. J. Dev. Biol. (1992) 36: 205-213 